\title{
Hypoxia Induces Paclitaxel-Resistance through ROS Production
}

\author{
Jin-Mi OH ${ }^{1}$, Yun-Kyoung RYu ${ }^{1}$, Jong-Seok LIM ${ }^{2}$, and Eun-Yi Moon ${ }^{1, *}$ \\ ${ }^{1}$ Department of Bioscience and Biotechnology, Sejong University, Seoul 143-747, \\ ${ }^{2}$ Department of Biological Sciences, Sookmyung Women's University, Seou 140-742, Republic of Korea
}

(Received January 27, 2010; Revised February 18, 2010; Accepted February 24, 2010)

\begin{abstract}
Oxygen supply into inside solid tumor is often diminished, which is called hypoxia. Many gene transcriptions were activated by hypoxia-inducible factor (HIF)-1 $\alpha$. Here, we investigated the effect of hypoxia on paclitaxel-resistance induction in HeLa cervical tumor cells. When HeLa cells were incubated under hypoxia condition, HIF-1 $\alpha$ level was increased. In contrast, paclitaxel-mediated tumor cell death was reduced by the incubation under hypoxia condition. Paclitaxel-mediated tumor cell death was also inhibited by treatment with DMOG, chemical HIF-1 $\alpha$ stabilizer, in a dose-dependent manner. A significant increase in intracellular ROS level was detected by the incubation under hypoxia condition. A basal level of cell density was increased in response to $10 \mathrm{nM} \mathrm{H}_{2} \mathrm{O}_{2}$. $\mathrm{HIF}-1 \alpha$ level was increased by treatment with various concentration of $\mathrm{H}_{2} \mathrm{O}_{2}$. The increased level of HIF-1 $\alpha$ by hypoxia was reduced by the treatment with $\mathrm{N}$-acetylcysteine (NAC), a well-known ROS scavenger. Paclitaxel-mediated tumor cell death was increased by treatment with NAC. Taken together, these findings demonstrate that hypoxia could play a role in paclitaxel-resistance induction through ROS-mediated HIF-1 $\alpha$ stabilization. These results suggest that hypoxia-induced ROS could, in part, control tumor cell death through an increase in HIF-1 $\alpha$ level.
\end{abstract}

Keywords: HeLa cell, Hypoxia, HIF-1 $\alpha$, ROS, Paclitaxel

\section{INTRODUCTION}

Hypoxia in cells and tissues contributes to the gene expression that participates in angiogenesis, vasorelaxation, metabolism, and cell proliferation/survival and resistance to anti-cancer drugs (Ke and Costa, 2006; Dong and Shin, 2008). Oxygen supply to the tumor cells is often diminished because tumor cells in solid tumor grow faster than the endothelial cells that build up the blood vessels (Folkman, 1990). Hypoxia in solid tumors is one of major causes to resistance against most anticancer drugs and, importantly, appears to accelerate malignant progression and increase metastasis (Hockel and Vaupel, 2001; Chan et al., 2007; Selvendiran et al., 2009). Transcription factor, hypoxia-inducible factor alpha (HIF)-1 plays an essential role in the cellular response to changes in oxygen tension (Papandreou et al., 2006).

HIF-1 is composed of two subunits, HIF- $1 \alpha$ and HIF- $1 \beta$ (Wang et al., 1995). While HIF-1 $\beta$ subunit is constitutively

${ }^{*}$ Corresponding author

Tel: +82-2-3408-3768 Fax: +82-2-3408-4334

E-mail: eunyimoon@sejong.ac.kr expressed, HIF-1 $\alpha$ subunit is inducible to hypoxia. Therefore, HIF-1 activity depends on the availability of the HIF- $1 \alpha$ subunit and provides a molecular basis for the adaptations of cancer cells to hypoxia (Semenza, 2000). HIF-1 $\alpha$ is rapidly degraded in normoxia (Salceda and Caro, 1997) but the degradation of HIF-1 $\alpha$ is inhibited in hypoxia (Huang et al., 1998). Many hypoxia-inducible genes are controlled by HIF-1 $\alpha$ (Wang et al., 1995).

Reactive oxygen species (ROS) can be produced by serum-deprivation, LPS-stimulation and peroxiredoxin II-deficiency (Moon, 2008; Kim and Moon, 2009). ROS cause tissue injury in one hand and promote tissue repair in another hand (Maulik and Das, 2002). Hypoxia-induced mitochondrial ROS have been shown to be necessary for the stabilization of HIF-1 in hypoxic cells (Brunelle et al., 2005; Guzy et al., 2005; Kaelin, 2005; Mansfield et al., 2005). Hypoxia activates gene transcription via a mitochondria-dependent signaling process that involves increased level of ROS (Chandel et al., 1998). HIF-1 $\alpha$ expression can be also induced through $\mathrm{H}_{2} \mathrm{O}_{2}$ production (Gao et al., 2004).

Paclitaxel is likely to play a major role as cancer chemotherapy in human malignancies. Paclitaxel blocks cells in the G2/M phase of the cell cycle and such cells are unable 
to form a normal mitotic apparatus. Microtubule cytoskeleton is reorganized by paclitaxel treatment and then it turns into extensive parallel arrays or stable bundles of microtubules in cells growing in tissue culture (Rowinsky et al., 1992; Martin, 1993; Horwitz, 1994). Paclitaxel-resistance is induced by ROS production and HIF-1 $\alpha$ stabilization during cancer treatment (Kim et al., 2008). However, little is known about whether hypoxia-induced ROS could lead to the drug-resistance to paclitaxel.

Here, we investigated the effect of hypoxia on paclitaxel-resistance induction in HeLa cervical tumor cells. Our data showed that hypoxia could play a role in tumor cell resistance to anticancer agents like paclitaxel through ROS-mediated HIF-1 $\alpha$ stabilization. It suggests that hypoxia-induced ROS could, in part, control tumor cell death to anti-cancer agents through HIF-1 $\alpha$ stabilization.

\section{MATERIALS AND METHODS}

\section{Reagents}

Antibodies which are reactive with HIF-1 $\alpha$ came from
BD Biosciences (San Jose, CA). 2,7-dichlorodihydrofluorescein diacetate (DCF-DA) was from Molecular Probes (Eugene, OR). Dimethyloxallyl glycine (DMOG) was from Cayman Chemical (Ann Arbor, MI). Except where indicated, all other materials are obtained from the Sigma chemical company (St. Louis, MO).

\section{Cell culture}

HeLa cells were obtained from the Korea Research Institute of Bioscience and Biotechnology (KRIBB) cell bank (Taejeon, Korea). Cells were maintained and cultured in Dulbecco's modified Eagle's medium supplemented with $10 \%$ fetal bovine serum (Hyclone, Kansas City, MO), $2 \mathrm{mM}$ L-glutamine, $100 \mathrm{units} / \mathrm{ml}$ penicillin, and 100 units/ml streptomycin.

\section{MTT assay}

We quantified paclitaxel-treated cell density using colorimetric assay described for measuring intracellular succinate dehydrogenase content with MTT [3(4,5-dimethylthiazol-2-yl)-2,5-diphenyl tetrazolium bromide] (Denizot
A.

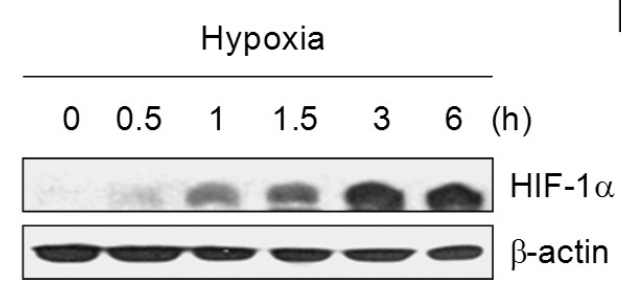

B.

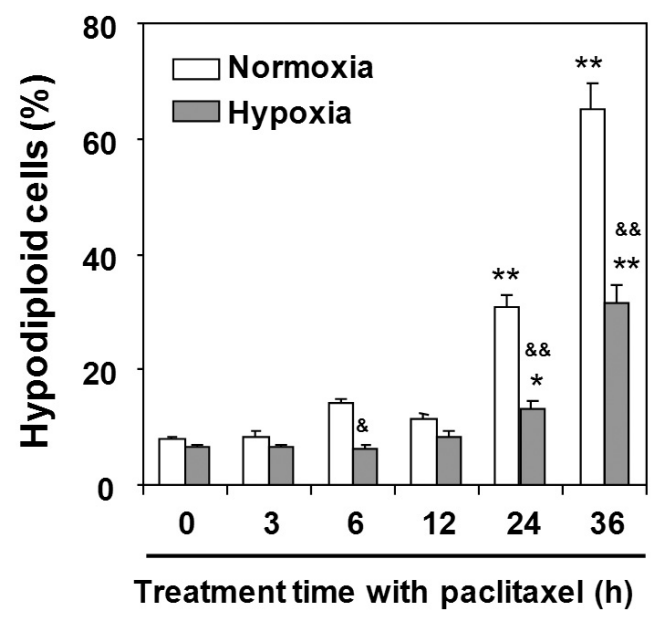

Fig. 1. Paclitaxel-mediated tumor cell death was decreased under hypoxia condition. (A) Cells were incubated in hypoxia condition for $0.5,1,1.5,3$, and $6 \mathrm{~h}$. Cell lysates were prepared and HIF-1 $\alpha$ was detected by western blot analysis. (B) Cells were incubated with $2 \mu \mathrm{M}$ paclitaxel for an appropriate time under normoxia or hypoxia condition. Then, cells were fixed and stained with propidium iodide $(50 \mu \mathrm{g} / \mathrm{ml})$ with RNase $(25 \mu \mathrm{g} / \mathrm{ml})$. Hypodiploid cells were analyzed with flow cytometry. ${ }^{*} p<0.05,{ }^{\star \star} p<$ 0.01 , hypodiploid cell population was significantly different from control in normoxia or hypoxia condition. ${ }^{\&} p<0.05,{ }^{\& \&} p<0.01$, hypodiploid cell population in hypoxia condition was significantly different from those in normoxia at each time point. (C) Cells were incubated with various concentrations of paclitaxel for $48 \mathrm{~h}$ in normoxia or hypoxia condition. Cell density was measured by MTT assay. Data represent mean \pm SED. ${ }^{*} p<0.05,{ }^{* *} p<0.01$, cell density in paclitaxel-treated group was significantly different from control. ${ }^{\#} p<0.05,{ }^{\#} p<0.01$, cell density in normoxia condition was significantly different from control in hypoxia condition at each concentration of paclitaxel. 
and Lang, 1986). Confluent cells were cultured with various concentrations of paclitaxel for 48 hour. Cells were then incubated with $50 \mu \mathrm{g} / \mathrm{ml}$ of MTT at $37^{\circ} \mathrm{C}$ for 2 hour. Formazan formed were dissolved in dimethylsulfoxide (DMSO). Optical density (OD) was read at $595 \mathrm{~nm}$.

\section{Western blot analysis}

Cells were lysed in ice-cold lysis buffer, containing $0.5 \%$ Nonidet P-40 (vol./vol.) in $20 \mathrm{mM}$ Tris- $\mathrm{HCl}$, at a $\mathrm{pH}$ of 8.3; $150 \mathrm{mM} \mathrm{NaCl}$; protease inhibitors $(2 \mu \mathrm{g} / \mathrm{ml}$ aprotinin, pepstatin, and chymostatin; $1 \mu \mathrm{g} / \mathrm{ml}$ leupeptin and pepstatin; 1 $\mathrm{mM}$ phenylmethyl sulfonyl fluoride (PMSF); and $1 \mathrm{mM}$ $\mathrm{Na}_{4} \mathrm{VO}_{3}$. Lysates were incubated for 30 minutes on ice prior to centrifugation at $14,000 \mathrm{rpm}$ for 5 minute at $4^{\circ} \mathrm{C}$. Proteins in the supernatant were denatured by boiling for 5 minute in sodium dodecyl sulfate (SDS) sample buffer. Proteins were separated by $12 \%$ SDS-polyacrylamide gel electrophoresis (SDS-PAGE), and then transferred to nitrocellulose membranes. Following this transfer, equal loading of protein was verified by Ponceau staining. The membranes were blocked with $5 \%$ skim milk in Tris-buffered saline with Tween 20 (TBST) (10 mM Tris- $\mathrm{HCl}, \mathrm{pH}$ 7.6; $150 \mathrm{mM} \mathrm{NaCl} ; 0.5 \%$ Tween 20), then incubated with the indicated antibodies. Bound antibodies were visualized with HRP-conjugated secondary antibodies with the use of enhanced chemiluminescence (ECL) (Pierce, Rockford, IL).

\section{Flow cytometry analysis}

Level of reactive oxygen species (ROS) was determined by incubating HeLa cells with $10 \mu \mathrm{M}$ DCF-DA for $30 \mathrm{mi}-$ nutes at $37^{\circ} \mathrm{C}$. The cells were detached by the incubation with $0.05 \%$ trypsin/EDTA (Invitrogen, Carlsbad, CA) for an additional 5 minute at $37^{\circ} \mathrm{C}$. Fluorescence intensity of 10,000 cells was analyzed by CELLQuest ${ }^{\mathrm{TM}}$ software in FACScalibur $^{\mathrm{TM}}$ (Becton Dickinson, San Jose, CA).

\section{Statistical analyses}

Experimental differences were tested for statistical significance using ANOVA and Students' t-test. $p$-value of $<$ 0.05 or $<0.01$ was considered to be significant.

\section{RESULTS}

\section{Paclitaxel-mediated tumor cell death was reduced by HIF-1 $\alpha$ stabilization.}

Given that actin-sequestering protein, thymosin beta 4 (TB4), induced a similar hypoxia condition and tumor cell density was increased by treatment with TB4 proteins (Oh et al., 2006; Oh et al., 2008), we investigated whether tu- mor cell density could be affected by paclitaxel treatment under hypoxia. HIF-1 $\alpha$ stabilization increased under our experimental hypoxia condition (Fig. 1A). To examine the effect of hypoxia on paclitaxel-mediated tumor cell death, we incubated HeLa cells in the presence of paclitaxel under normoxia or hypoxia condition. A time-dependent increase in paclitaxel-induced hypodiploid cell formation was twice as much lower under hypoxia conditions compared to normoxia (Fig. 1B). When we also measured HeLa cell density rate in response to paclitaxel treatment by MTT assay, it was $40 \%$ higher under hypoxia conditions relative to normoxia (Fig. 1C). In addition, paclitaxel-mediated tumor cell death was inhibited by treatment with DMOG, chemical HIF-1 $\alpha$ stabilizer, in a dose-dependent manner (Fig.
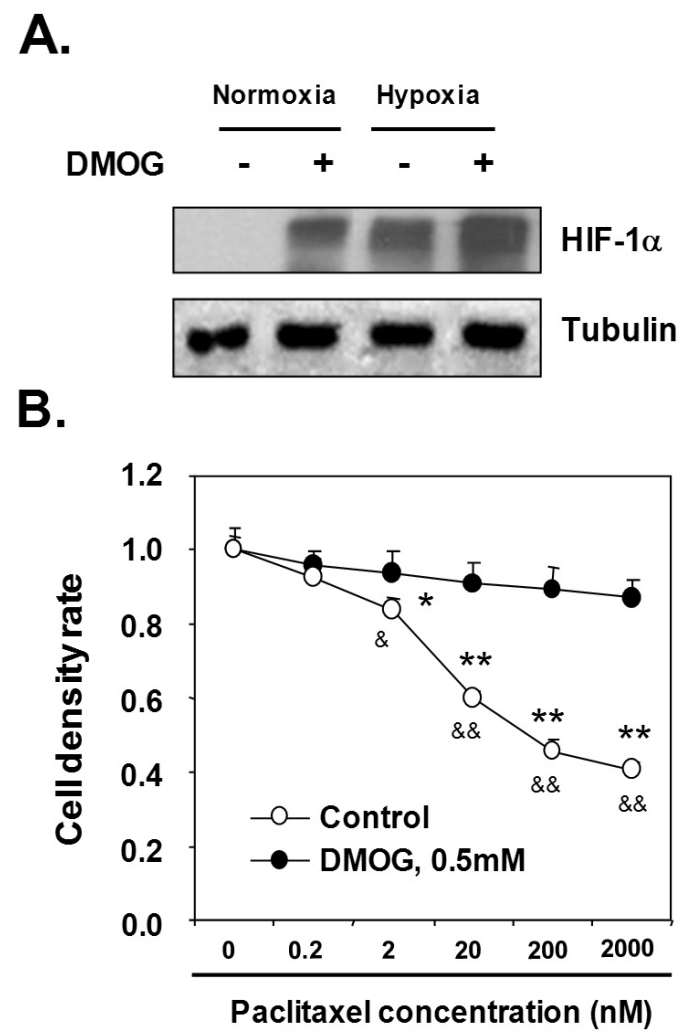

Fig. 2. Chemical HIF-1 $1 \alpha$ stabilizer, dimethyloxallyl glycine (DMOG), inhibited paclitaxel-mediated tumor cell death. (A) Cells were incubated in the presence or absence of DMOG in normoxia condition. Cell lysates were prepared and HIF-1 $\alpha$ was detected by western blot analysis. (B) Cells were incubated with various concentrations of paclitaxel for $48 \mathrm{~h}$ in the presence or absence of DMOG under normoxia condition. Cell density was measured by MTT assay. Data represent mean \pm SED. ${ }^{*} p<$ $0.05,{ }^{* *} p<0.01$, cell density in paclitaxel-treated group was significantly different from control. ${ }^{\&} p<0.05,{ }^{\& \&} p<0.01$, cell density in DMOG-untreated group was significantly different from DMOG-treated group. 


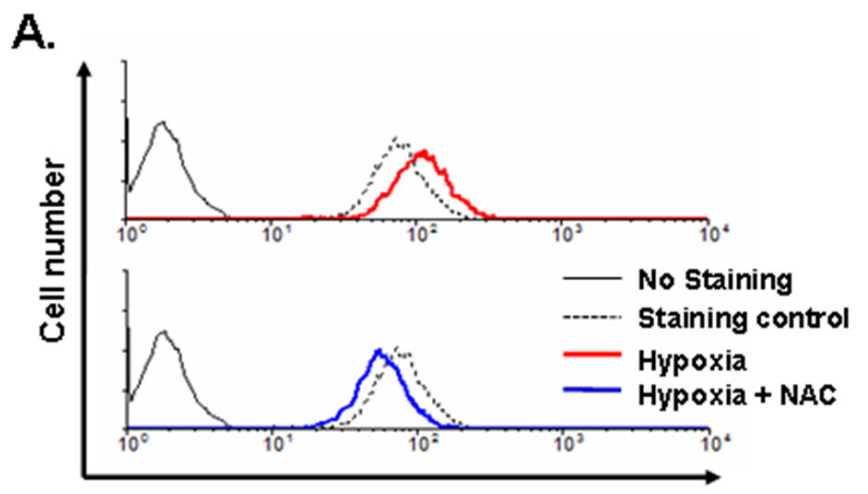

Fluorescent intensity

B.

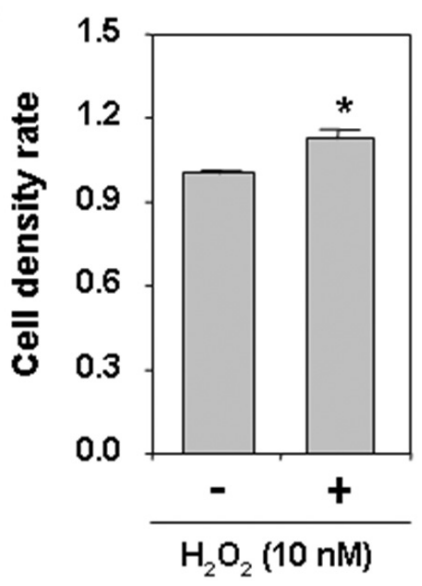

Fig. 3. Hypoxia increased ROS production. (A) Cells were incubated in hypoxic condition for $1 \mathrm{~h}$ in the presence or absence of NAC, ROS scavenger. Then, cells were incubated with DCF-DA for $30 \mathrm{~min}$ to detect intracellular ROS. Cells were analyzed with flow cytometry. (B) Cells were incubated for $24 \mathrm{~h}$ in the presence or absence of $10 \mathrm{nM} \mathrm{H}_{2} \mathrm{O}_{2}$ under normoxia condition. Cell density was measured by MTT assay. Data represent mean \pm SED. ${ }^{*} p<0.05$, cell density in $\mathrm{H}_{2} \mathrm{O}_{2}$-treated group was significantly different from control.

2). These findings suggest that resistance to paclitaxel-mediated tumor cell death could be induced by HIF-1 $\alpha$ stabilization under hypoxia condition.

\section{ROS scavenger, NAC, aggravated paclitaxel-mediated tumor cell death under hypoxia}

Given that hypoxia-induced mitochondrial ROS have been shown to be necessary for the stabilization of HIF-1 in hypoxic cells (Guzy et al., 2005; Kaelin, 2005; Mansfield et al., 2005), we examined if ROS could be produced under hypoxia. As shown in Fig. 3A, intracellular ROS production was increased under hypoxia, which was decreased by pretreatment with $\mathrm{N}$-acetylcysteine (NAC). Our previous data showed that tumor cell density was de-
A.

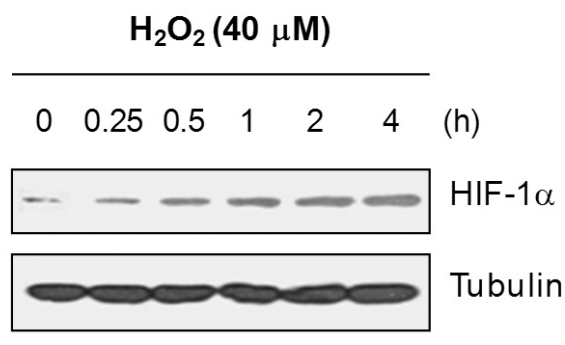

B.

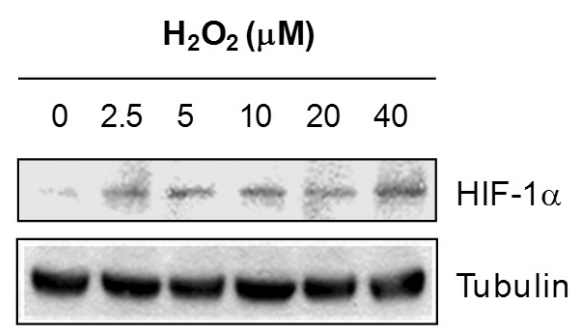

Fig. 4. HIF-1 $\alpha$ level was increased by treatment with $\mathrm{H}_{2} \mathrm{O}_{2}$. (A) Cells were incubated with $40 \mu \mathrm{M} \mathrm{H}_{2} \mathrm{O}_{2}$ for an appropriate time. (B) Cells were incubated with various concentration of $\mathrm{H}_{2} \mathrm{O}_{2}$ for $1 \mathrm{~h}$. Then, cell lysates were prepared and HIF-1 $\alpha$ was detected by Western blot analysis.

creased by the incubation with $20 \mathrm{mM}$ or $40 \mathrm{mM}$ NAC (Kim et al., 2008). Fig. 3B showed that tumor cell density was increased when cells were treated with $10 \mathrm{nM} \mathrm{H}_{2} \mathrm{O}_{2}$. In contrast, tumor cell density was decreased in response to $\mathrm{H}_{2} \mathrm{O}_{2}$ treatment at concentrations higher than $10 \mu \mathrm{M} \mathrm{H}_{2} \mathrm{O}_{2}$ (data not shown). We also examined the effect of $\mathrm{H}_{2} \mathrm{O}_{2}$ on HIF- $1 \alpha$ stabilization. As shown in Fig. $4 \mathrm{~A}, 40 \mu \mathrm{M} \mathrm{H}_{2} \mathrm{O}_{2}$ enhanced HIF- $1 \alpha$ level in a time-dependent manner. HIF- $1 \alpha$ level was also increased by treatment with various concentration of $\mathrm{H}_{2} \mathrm{O}_{2}$ (Fig. 4B). When cells were pretreated with NAC, HIF-1 $\alpha$ stabilization was reduced (Fig. 5A). It implicates that paclitaxel-mediated tumor cell death could be affected by hypoxia-induced ROS production through HIF-1 $\alpha$ stabilization.

To examine the effect of hypoxia-induced ROS on paclitaxel-mediated cell death, cells were incubated with various concentrations of paclitaxel in the presence or absence of NAC under hypoxia. As shown in Fig. 5B, paclitaxel-mediated tumor cell death was aggravated by the incubation with NAC. These findings suggest that paclitaxel-resistance could be established by hypoxia-induced ROS production and a consequent HIF-1 $\alpha$ stabilization.

\section{DISCUSSION}

Hypoxia occurs naturally in physiological settings, as 
A.

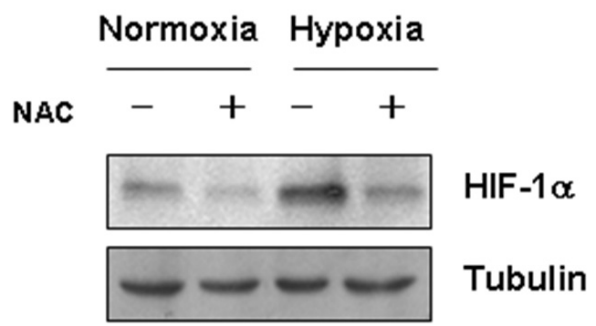

B.

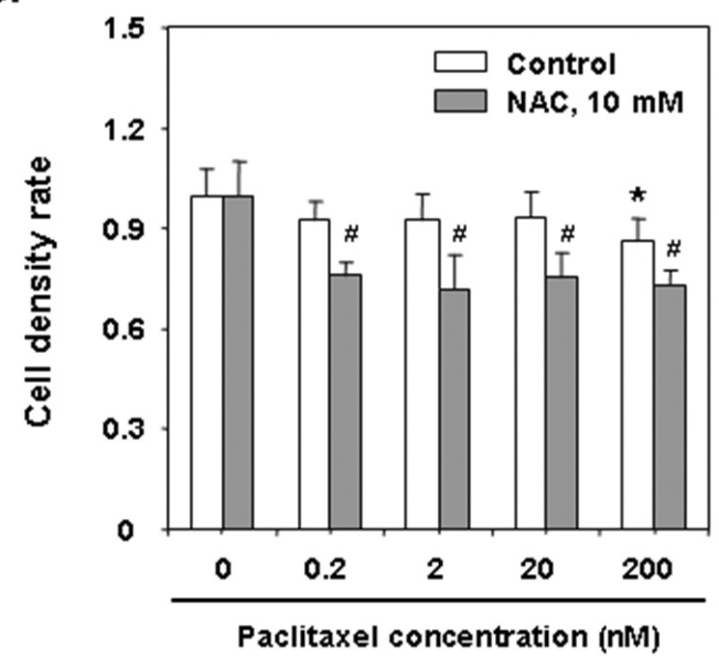

Fig. 5. Hypoxia-induced paclitaxel-resistance was reduced by treatment with NAC. (A) Cells were pretreated with $10 \mathrm{mM} \mathrm{NAC}$ for $12 \mathrm{~h}$ and then incubated under hypoxic condition for $1 \mathrm{~h}$ in the presence or absence of NAC. Cell lysates were prepared and HIF-1 $\alpha$ was detected by Western blot analysis. (B) Cells were pretreated with $10 \mathrm{mM}$ NAC for $12 \mathrm{~h}$ and then incubated with paclitaxel for $48 \mathrm{~h}$ in the presence or absence of NAC under hypoxia condition. Cell density was measured by MTT assay. Data represent mean \pm SED. ${ }^{*} p<0.05$, cell density in paclitaxel-treated group was significantly different from control. ${ }^{\#} p<0.05$, cell density in paclitaxel- and NAC-treated group was significantly different from paclitaxel-treated but NAC-untreated group.

well as in pathophysiological conditions (Simon, 2006). Hypoxia in solid tumors is not only a major problem for radiation therapy but also leads to resistance against most anticancer drugs (Hockel and Vaupel, 2001; Chan et al., 2007; Selvendiran et al., 2009). Adaptations of cancer cells to hypoxia are critical for the establishment of a primary tumor and its progression to the lethal phenotype (Semenza, 2000) by stimulating HIF-1 and by activating transcription of target genes (Zhong et al., 1999). Previous reports showed that physiological or pathophysiological hypoxia increased ROS production and HIF-1 $\alpha$ stabilization (Simon, 2006; Guzy et al., 2008). Here, we inves- tigated the effect of hypoxia on paclitaxel-resistance induction in HeLa cervical tumor cells through ROS production. We found that HeLa cells increased HIF-1 $\alpha$ level (Fig. $1 \mathrm{~A}$ ) and produced ROS (Fig. 3) under hypoxia. ROS-mediated HIF-1 $\alpha$ stabilization was re-affirmed by treatment with NAC under hypoxia (Fig. 5A). Our data also showed that hypoxia could play a role in tumor cell resistance to anticancer agents like paclitaxel through ROS-mediated HIF-1 $\alpha$ stabilization.

A few explanations are possible for the role of hypoxia-induced ROS on paclitaxel-resistance through HIF-1 $\alpha$ stabilization. One explanation is that hypoxia-induced ROS could reduce the apoptosis by paclitaxel treatment. This was supported by the data that $10 \mathrm{nM} \mathrm{H}_{2} \mathrm{O}_{2}$ increased tumor cell density (Fig. 3B) and NAC treatment reduced cell density (Kim et al., 2008). The other explanation is that ROS activate NFKB-dependent signaling pathway and directly increased not only HIF-1 $\alpha$ expression (Jung et al., 2003; Belaiba et al., 2007) but also other genes inducing drug-resistance. Nuclear translocation of NF-KB can be triggered by exposure to $\mathrm{H}_{2} \mathrm{O}_{2}$ (Janssen-Heininger et al., 2000) and facilitated by conditions associated with increased intracellular oxidative stress (Toledano and Leonard, 1991). NF-kB can be activated by Ras/ERK/NF-kB pathways (Han et al., 2006). Therefore, hypoxia-induced ROS production may be involved in Ras/ERK/NF-kB pathways to enhance HIF-1 $\alpha$ expression. PI3K/AKT pathway is another candidate to increase HIF-1 $\alpha$ expression. Hypoxia induces HIF-1 $\alpha$ mRNA expression via the PI3K/AKT pathway and activation of NF-kB (Belaiba et al., 2007). It could not be ruled out that ROS also affects other molecular pathways in addition to HIF-1 $\alpha$ stabilization. p70S6K1 may be another molecule that is activated by ROS produced from treatment with EGF or insulin (Liu et al., 2006; Zhou et al., 2007). Paclitaxel-resistance was also induced by thymosin beta 4 (TB4) gene-overexpression (Oh et al., 2006) and TB4 proteins induced HIF-1 $\alpha$ stabilization (Oh et al., 2008). Therefore, HIF-1 $\alpha$ stabilization under all hypoxia conditions may interfere with the effects of anti-tumor agents like paclitaxel and induce the drug-resistance through ROS production

In conclusion, even though we could not explain all of the mechanisms responsible for the regulation of cell death decreased by hypoxia-mediated ROS production in regards to paclitaxel-resistance induction, our data clearly demonstrate that ROS stabilized HIF- $1 \alpha$, which inhibits paclitaxel-mediated tumor cell death and may have induced anti-tumor drug-resistance. These findings suggest that hypoxia-induced ROS could, in part, control tumor cell death through an increase in HIF-1 $\alpha$ level. 


\section{ACKNOWLEDGMENTS}

This work was supported by a Grants from the National R\&D Program (\#0920270) for Cancer Control, Ministry for Health, Welfare and Family affairs, and the Nanotoxicology Program (\#08162 KFDA545), Korea Food \& Drug Administration, Republic of Korea.

\section{REFERENCES}

Belaiba, R. S., Bonello, S., Zahringer, C., Schmidt, S., Hess, J., Kietzmann, T. and Gorlach, A. (2007). Hypoxia up-regulates hypoxia-inducible factor-1alpha transcription by involving phosphatidylinositol 3-kinase and nuclear factor kappaB in pulmonary artery smooth muscle cells. Mol. Biol. Cell 18 , 4691-4697.

Brunelle, J. K., Bell, E. L., Quesada, N. M., Vercauteren, K., Tiranti, V., Zeviani, M., Scarpulla, R. C. and Chandel, N. S. (2005). Oxygen sensing requires mitochondrial ROS but not oxidative phosphorylation. Cell Metab. 1, 409-414.

Chan, D. A., Krieg, A. J., Turcotte, S. and Giaccia, A. J. (2007). HIF gene expression in cancer therapy. Methods Enzymol. 435, 323-345.

Chandel, N. S., Maltepe, E., Goldwasser, E., Mathieu, C. E., Simon, M. C. and Schumacker, P. T. (1998). Mitochondrial reactive oxygen species trigger hypoxia-induced transcription. Proc. Natl. Acad. Sci. U. S. A. 95, 11715-11720.

Denizot, F. and Lang, R. (1986). Rapid colorimetric assay for cell growth and survival. Modifications to the tetrazolium dye procedure giving improved sensitivity and reliability. J. Immunol. Methods 89, 271-277.

Dong, J. E. H. and Shin, C. Y. (2008). Vasorelaxing effect of hypoxia via Rho-kinase inhibition on the agonist-specific vasoconstriction. Biomol. \& Ther. 16, 249-254.

Folkman, J. (1990). What is the evidence that tumors are angiogenesis dependent? J. Natl. Cancer Inst. 82, 4-6.

Gao, N., Shen, L., Zhang, Z., Leonard, S. S., He, H., Zhang, X. G., Shi, X. and Jiang, B. H. (2004). Arsenite induces HIF1alpha and VEGF through PI3K, Akt and reactive oxygen species in DU145 human prostate carcinoma cells. Mol. Cell Biochem. 255, 33-45.

Guzy, R. D., Hoyos, B., Robin, E., Chen, H., Liu, L., Mansfield, K. D., Simon, M. C., Hammerling, U. and Schumacker, P. T. (2005). Mitochondrial complex III is required for hypoxiainduced ROS production and cellular oxygen sensing. Cell Metab. 1, 401-408.

Guzy, R. D., Sharma, B., Bell, E., Chandel, N. S. and Schumacker, P. T. (2008). Loss of the SdhB, but Not the SdhA, subunit of complex II triggers reactive oxygen speciesdependent hypoxia-inducible factor activation and tumorigenesis. Mol. Cell Biol. 28, 718-731.

Han, Y. H., Kwon, J. H., Yu, D. Y. and Moon, E. Y. (2006). Inhibitory effect of peroxiredoxin II (Prx II) on Ras-ERKNFkappaB pathway in mouse embryonic fibroblast (MEF) senescence. Free Radic. Res. 40, 1182-1189.

Hockel, M. and Vaupel, P. (2001). Tumor hypoxia: definitions and current clinical, biologic, and molecular aspects. J. Natl. Cancer Inst. 93, 266-276.
Horwitz, S. B. (1994). Taxol (paclitaxel): mechanisms of action. Ann. Oncol. 5(Suppl 6), S3-6.

Huang, L. E., Gu, J., Schau, M. and Bunn, H. F. (1998). Regulation of hypoxia-inducible factor 1alpha is mediated by an O2-dependent degradation domain via the ubiquitinproteasome pathway. Proc. Natl. Acad. Sci. U. S. A. 95, 7987- 7992.

Janssen-Heininger, Y. M., Poynter, M. E. and Baeuerle, P. A (2000). Recent advances towards understanding redox mechanisms in the activation of nuclear factor kappaB. Free Radic. Biol. Med. 28, 1317-1327.

Jung, Y. J., Isaacs, J. S., Lee, S., Trepel, J. and Neckers, L. (2003). Microtubule disruption utilizes an NFkappa B-dependent pathway to stabilize HIF-1alpha protein. J. Biol. Chem. 278, 7445-7452.

Kaelin, W. G. Jr. (2005). ROS: really involved in oxygen sensing. Cell Metab. 1, 357-358.

$\mathrm{Ke}, \mathrm{Q}$. and Costa, M. (2006). Hypoxia-inducible factor-1 (HIF-1). Mol. Pharmacol. 70, 1469-1480.

Kim, H. S. and Moon, E. Y. (2009). Reactive oxygen speciesinduced expression of $B$ cell activating factor (BAFF) is independent of toll-like receptor 4 and myeloid differentiation primary response gene 88 . Biomol. \& Ther. 17, 144-150.

Kim, H. S., Oh, J. M., Jin, D. H., Yang, K. H. and Moon, E. Y. (2008). Paclitaxel induces vascular endothelial growth factor expression through reactive oxygen species production. Pharmacology 81, 317-324.

Liu, L. Z., Hu, X. W., Xia, C., He, J., Zhou, Q., Shi, X., Fang, J. and Jiang, B. H. (2006). Reactive oxygen species regulate epidermal growth factor-induced vascular endothelial growth factor and hypoxia-inducible factor-1alpha expression through activation of AKT and P70S6K1 in human ovarian cancer cells. Free Radic. Biol. Med. 41, 1521-1533.

Mansfield, K. D., Guzy, R. D., Pan, Y., Young, R. M., Cash, T. P., Schumacker, P. T. and Simon, M. C. (2005). Mitochondrial dysfunction resulting from loss of cytochrome $\mathrm{c}$ impairs cellular oxygen sensing and hypoxic HIF-alpha activation. Cell Metab. 1, 393-399.

Martin, V. (1993). Overview of paclitaxel (TAXOL). Semin. Oncol. Nurs. 9, 2-5.

Maulik, N. and Das, D. K. (2002). Redox signaling in vascular angiogenesis. Free Radic. Biol. Med. 33, 1047-1060.

Moon, E. Y. (2008). Serum deprivation enhances apoptoticcell death by increasing mitochondrial enzyme aActivity. Biomol. \& Ther. 16, 1-8

Oh, J. M., Ryoo, I. J., Yang, Y., Kim, H. S., Yang, K. H. and Moon, E. Y. (2008). Hypoxia-inducible transcription factor (HIF)-1 alpha stabilization by actin-sequestering protein, thymosin beta-4 (TB4) in Hela cervical tumor cells. Cancer Lett. 264, 29-35.

Oh, S. Y., Song, J. H., Gil, J. E., Kim, J. H., Yeom, Y. I. and Moon, E. Y. (2006). ERK activation by thymosin-beta-4 (TB4) overexpression induces paclitaxel-resistance. Exp. Cell Res. 312, 1651-1657.

Papandreou, I., Cairns, R. A., Fontana, L., Lim, A. L. and Denko, N. C. (2006). HIF-1 mediates adaptation to hypoxia by actively downregulating mitochondrial oxygen consumption. Cell Metab. 3, 187-197.

Rowinsky, E. K., Onetto, N., Canetta, R. M. and Arbuck, S. G. (1992). Taxol: the first of the taxanes, an important new class 
of antitumor agents. Semin. Oncol. 19, 646-662.

Salceda, S. and Caro, J. (1997). Hypoxia-inducible factor 1alpha (HIF-1alpha) protein is rapidly degraded by the ubiquitinproteasome system under normoxic conditions. Its stabilization by hypoxia depends on redox-induced changes. $J$. Biol. Chem. 272, 22642-22647.

Selvendiran, K., Bratasz, A., Kuppusamy, M. L., Tazi, M. F., Rivera, B. K. and Kuppusamy, P. (2009). Hypoxia induces chemoresistance in ovarian cancer cells by activation of signal transducer and activator of transcription 3. Int. J. Cancer 125, 2198-2204.

Semenza, G. L. (2000). HIF-1: using two hands to flip the angiogenic switch. Cancer Metastasis Rev. 19, 59-65.

Simon, M. C. (2006). Coming up for air: HIF-1 and mitochondrial oxygen consumption. Cell Metab. 3, 150-151.

Toledano, M. B. and Leonard, W. J. (1991). Modulation of trans- cription factor NF-kappa B binding activity by oxidationreduction in vitro. Proc. Natl. Acad. Sci. U. S. A. 88, 4328-4332.

Wang, G. L., Jiang, B. H., Rue, E. A. and Semenza, G. L. (1995). Hypoxia-inducible factor 1 is a basic-helix-loop-helixPAS heterodimer regulated by cellular $\mathrm{O} 2$ tension. Proc. Natl. Acad. Sci. U. S. A. 92, 5510-5514.

Zhong, H., De Marzo, A. M., Laughner, E., Lim, M., Hilton, D. A., Zagzag, D., Buechler, P., Isaacs, W. B., Semenza, G. L. and Simons, J. W. (1999). Overexpression of hypoxia-inducible factor 1alpha in common human cancers and their metastases. Cancer Res. 59, 5830-5835.

Zhou, Q., Liu, L. Z., Fu, B., Hu, X., Shi, X., Fang, J. and Jiang, B. $H$. (2007). Reactive oxygen species regulate insulin-induced VEGF and HIF-1alpha expression through the activation of p70S6K1 in human prostate cancer cells. Carcinogenesis 28, 28-37. 